\title{
PERTUMBUHAN PENJUALAN, JAMINAN ASET, UKURAN PERUSAHAAN, RETURN ON EQUITY, CURRENT RATIO, DAN EARNINGS PER SHARE TERHADAP KEBIJAKAN DIVIDEN PADA SEKTOR OTOMOTIF
}

\author{
ELIYANTI \\ STELLA \\ Trisakti School of Management, Jl. Kyai Tapa No. 20 Jakarta 11440, Indonesia \\ eliyanti660@gmail.com
}

\begin{abstract}
The purpose of this study was to determine the effect of Sales Growth, Collateral Asset, Firm size, Return on Equity, Current Ratio and Earnings per Share on the Dividend Policy on automotive sector in Indonesia Stock Exchange. Population of this research are automotive companies listed in Indonesia Stock Exchange from 20122015. The samples of this study are 8 companies using purposive sampling method. This research uses multiple regression method for data analysis. The result of this study shows that Collateral Asset have influence to dividend policy. Sales Growth, Firm Size, Return on Equity, and Earnings per Share do not have influence to capital structure.
\end{abstract}

Keywords: Sales growth, collateral asset, firm size, return on equity, current ratio, earnings per share, dividend policy

Abstrak: Tujuan penelitian adalah untuk mengetahui pengaruh pertumbuhan penjualan, jaminan aset, ukuran perusahaan, return on equity, current ratio dan earnings per share secara terhadap kebijakan dividen pada sektor otomotif di Bursa Efek Indonesia. Objek penelitian ini adalah perusahaan otomotif yang terdaftar pada Bursa Efek Indonesia selama tahun 2012-2015. Teknik pengumpulan sampel yang digunakan adalah metode purposive sampling, dimana 8 perusahaan memenuhi kriteria. Penelitian ini menggunakan metode regresi berganda untuk menganalisis data. Hasil dari penelitian ini adalah terdapat pengaruh jaminan aset terhadap kebijakan dividen. Sedangkan pertumbuhan penjualan, ukuran perusahaan, return on equity, current ratio dan earnings per share tidak memiliki pengaruh terhadap kebijakan dividen.

Kata kunci: Pertumbuhan penjualan, jaminan aset, ukuran perusahaan, return on equity, current ratio, earnings per share , kebijakan dividen

\section{PENDAHULUAN}

Pada era perekonomian di Indonesia yang semakin berkembang ini, mengakibatkan munculnya beberapa perusahaan baru yang ingin meningkatkan persaingannya yang semakin ketat dengan perusahaan yang sudah ada. Banyak perusahaan bersaing untuk mendapatkan investor. Sehingga perusahaan tersebut menawarkan berbagai keuntungan kepada investor, agar investor tertarik dengan perusahaan tersebut.

Sumber dana terbagi menjadi dua yaitu sumber eksternal dan sumber internal. Sumber eksternal didapat dari investor yang menanamkan modalnya pada perusahaan serta 
kreditur yang memberikan dana pinjaman, sedangkan sumber internal berasal dari keuntungan yang dihasilkan oleh perusahaan serta laba yang ditahan oleh perusahaan. Berkaitan dengan keuntungan yang didapat oleh perusahaan maka ada hak para investor didalamnya berupa pembagian hasil keuntungan yang berupa kebijakan perusahaan dalam pembagian dividend (kebijakan dividen). Penelitian ini merupakan pengembangan dari penelitian yang dilakukan oleh Darmayanti dan Mustanda (2016) dengan judul penelitian "Pengaruh Pertumbuhan Penjualan, Jaminan Aset, dan Ukuran Perusahaan Terhadap Kebijakan Dividen pada Sektor Industri Barang Konsumsi" dengan menambahkan faktor-faktor yang ada dengan judul "Pengaruh Return on Equity, Current Ratio dan Earning Per Share Terhadap Kebijakan Dividen pada Perusahaan Keuangan". Objek penelitian ini adalah perusahaan Automotive yang terdaftar di Bursa Efek Indonesia.

Masalah penelitian ini adalah apakah pertumbuhan penjualan, jaminan aset, ukuran perusahaan, return on equity, current ratio dan earning per share berpengaruh terhadap kebijakan dividen pada sektor otomotif yang terdaftar di BEI periode 2012-2015. Tujuan penelitian ini adalah untuk mengetahui pengaruh pertumbuhan penjualan, jaminan aset, ukuran perusahaan, return on equity, current ratio dan earning per share terhadap kebijakan dividen pada sektor otomotif yang terdaftar di BEI periode 2012-2015. Sistematika dari penulisan ini adalah pendahuluan, kerangka teoritis dan pengembangan hipotesis, metode penelitian, analisis dan pembahasan, dan penutup.

\section{Signalling Theory}

Menurut Gitman dan Zutter $(2015,586)$ "signalling theory, a financing action by management that is believed to reflect its view of the firm's stock value; generally, debt financing is viewed as a positive signal that management believes the stock is overvalued".

\section{Agency Theory}

Terdapat perbedaan kepentingan antara manajer dan pemegang saham. Hal ini terjadi pertentangan antara kepentingan individu dengan kepentingan perusahaan. Ada kecenderungan manajer lebih mementingkan kepentingan individu daripada kepentingan perusahaan.

\section{Residual Theory of Dividends}

Teori dividen residual menyatakan bahwa ketika perusahaan akan memutuskan berapa banyak uang kas yang harus dibagikan kepada pemegang saham, ada dua hal yang harus tetap diingat, yaitu: (1) tujuan utamanya adalah untuk memaksimumkan nilai pemegang saham, dan (2) arus kas yang dihasilkan perusahaan merupakan milik pemegang saham.

\section{Kebijakan Dividen}

Dividend payout ratio is indicates the percentage of each dollar earned that a firm distributes to the owners in the form of cash (Gitman dan Zutter 2015, 630). Dividend payout ratio adalah persentase dari perbandingan dividen per lembar saham dengan laba perlembar saham. Kebijakan dividen sangat penting untuk manajer dan investor, karena kebijakan dividen tidak hanya sebagai sumber pendapatan bagi investor, tetapi juga mencerminkan kinerja perusahaan. Dividend payout ratio merupakan persentase setiap keuntungan yang diperoleh dan distribusikan kepada pemegang saham dalam bentuk uang tunai, serta menjadi tolak ukur untuk membagikan dividen kepada pemegang saham.

\section{Pertumbuhan Penjualan dan Kebijakan Dividen}

Menurut Kesuma $(2009,41)$ "growth of sales adalah kenaikan jumlah penjualan dari tahun ke tahun atau dari waktu ke waktu". 
Pertumbuhan penjualan merupakan selisih antara jumlah penjualan periode ini dengan periode sebelumnya dibandingkan dengan penjualan periode sebelumnya (Suweta dan Dewi 2016, 5177).

Dari penjelasan diatas, dapat disimpulkan bahwa pertumbuhan penjualan adalah kenaikan penjualan dari tahun sebelumnya ke tahun berikutnya. Perusahaan yang terus mengalami pertumbuhan dalam penjualannya akan berakibat pada keuntungan yang diterima oleh perusahaan akan meningkat. Jika keuntungan perusahaan meningkat maka perusahaan memiliki kemampuan untuk membayar dividen kepada para investor.

Hal ini di dukung oleh penelitian sebelumnya yang dilakukan oleh Darmayanti dan Mustanda (2016) yang menyatakan bahwa tidak terdapat pengaruh yang signifikan pertumbuhan penjualan dengan kebijakan dividen. Berbeda dengan hasil penelitian Winatha (2001), Dhailami (2006) dan Nurmadinah (2014) yang menyatakan bahwa secara parsial pertumbuhan penjualan berpengaruh positif terhadap dividend payout ratio (DPR).

$\mathrm{H}_{1}$ Terdapat pengaruh pertumbuhan penjualan terhadap kebijakan dividen.

\section{Jaminan Aset dan Kebijakan Dividen}

Pada umumnya utang jangka panjang yang berjaminan akan lebih murah daripada utang tanpa jaminan". Perusahaan cenderung kurang mengandalkan laba ditahan dalam kegiatan pendanaannya sehingga kecil kemungkinan pemegang obligasi akan membatasi kebijakan dividen perusahaan (Santoso, 2012).

Berdasarkan pernyataan diatas dapat disimpulkan bahwa, keuntungan perusahaan merupakan faktor pertama yang biasanya menjadi pertimbangan direksi, walaupun untuk membayar deviden perusahaan rugipun dapat melaksanakannya, karena adanya cadangan dalam bentuk laba ditahan. Oleh karena itu semakin besar jaminan aset, semakin besar pula dividen yang akan dibagikan.

Hal ini didukung oleh penelitian sebelumnya yang dilakukan oleh Darmayanti dan Mustanda (2016) yang memiliki pengaruh yang signifikan jaminan aset terhadap kebijakan dividen. Berbeda dengan penelitian Setiawan dan Etna (2013) yang menyatakan bahwa jaminan aset negatif terhadap kebijakan dividen. $\mathrm{H}_{2}$ Terdapat pengaruh jaminan aset terhadap kebijakan dividen.

\section{Ukuran Perusahaan dan Kebijakan Dividen}

Ukuran perusahaan merupakan gambaran kemampuan finansial perusahaan dalam suatu periode tertentu ( Isabella 2017). Ukuran perusahaan (firm size) adalah suatu ukuran atau besarnya sebuah perusahaan yang dapat dilihat dengan besarnya aktiva yang dimiliki oleh perusahaan.

Dari pernyataan diatas dapat disimpulkan bahwa firm size adalah ukuran besar kecilnya perusahaan yang dilihat pada nilai total aset perusahaan. Ukuran perusahaan juga menjadi salah satu faktor yang mempengaruhi keputusan pembagian dividen, suatu perusahaan yang sudah berkembang dan mampu bertahan dalam persaingan usaha selama kurun waktu tertentu akan memiliki akses yang lebih mudah menuju pasar modal dibandingkan perusahaan kecil yang masih baru dan tidak stabil sehingga mampu memperoleh dana yang lebih besar sehingga perusahaan mampu memiliki rasio pembayaran dividen yang lebih tinggi.

Hal tersebut sejalan dengan hasil penelitian sebelumnya dari Darmayanti dan Mustanda (2016) bahwa ukuran perusahaan tidak berpengaruh signifikan terhadap kebijakan dividen. Namun berbeda dengan hasil penelitian Dyah (2010) yang menyatakan bahwa ukuran perusahaan memiliki pengaruh positif dan signifikan terhadap DPR.

$\mathrm{H}_{3}$ : Terdapat pengaruh ukuran perusahaan terhadap kebijakan dividen. 


\section{Return on Equity dan Kebijakan Dividen}

Menurut Gitman dan Zutter $(2015,130)$

"Return on equity measures the return earned on the common stockholder's investment in the firm." Menurut Wiagustini $(2010,81)$ "return on equity merupakan rasio yang digunakan untuk mengukur kemampuan perusahaan dalam menghasilkan laba terhadap modal sendiri".

Berdasarkan pernyataan diatas, dapat disimpulkan bahwa return on equity (ROE) akan menunjukkan seberapa besar imbal hasil bisnis terhadap ekuitas yang merupakan hak sebagai investor. Semakin sedikit dividen yang dibagikan, maka semakin besar potensi pertumbuhan laba di masa depan, karena semakin besar bagian dari laba bersih yang dipergunakan untuk menambah modal usaha. Mardaleni (2014) menyatakan bahwa return on equity tidak berpengaruh terhadap kebijakan dividen.

$\mathrm{H}_{4}$ Terdapat pengaruh return on equity terhadap kebijakan dividen.

\section{Current Ratio dan Kebijakan Dividen}

Gitman dan Zutter (2015, 119) menyatakan bahwa "the current ratio, one of the most commonly cited financial ratio, measures the firm's ability to meet its short term obligations." Menurut Keown et al. $(2014,136)$ "current ratio measures a firm's liquidity. A higher ratio means a greater liquidity."

Berdasarkan teori-teori yang di jelaskan di atas, dapat disimpulkan bahwa current ratio adalah rasio yang mengukur kemampuan perusahaan memenuhi kewajiban jangka pendeknya. Sehingga current ratio berpengaruh pada kemampuan perusahaan membayar dividen kepada para investor.
Dewi (2014), dan Setiowati (2013) memiliki pengaruh positif dan signifikan current ratio terhadap kebijakan dividen. Malah berbanding terbalik dengan hasil penelitian dari Muhammadinah dan Jamil (2015) menunjukkan bahwa current ratio tidak berpengaruh signifikan terhadap kebijakan dividen.

$\mathrm{H}_{5}$ : Terdapat pengaruh current ratio terhadap kebijakan dividen.

\section{Earning Per Share dan Kebijakan Dividen}

Menurut Gitman dan Zutter $(2015,129)$

"earning per share is the number of dollars earned during the period on behalf of each outstanding share of common stock". Menurut Wiagustini $(2010,81)$ "earning per share merupakan alat ukur yang digunakan mengukur pengakuan pasar terhadap kondisi perusahaan untuk mengetahui jumlah laba per saham.

Berdasarkan pernyataan diatas dapat disimpulkan bahwa earning per share yang tinggi mencerminkan suatu perusahaan berhasil mengelola keuangannya, sehingga dapat membagikan laba dalam bentuk dividen dan meningkatkan minat para pemegang saham untuk berinvestasi. Dentiana (2009) menunjukan bahwa terdapat pengaruh earning per share terhadap kebijakan dividen.

$\mathrm{H}_{6}$ : Terdapat pengaruh earning per share terhadap kebijakan dividen.

\section{Model Penelitian}

Model penelitian ini terdiri dari variabel dependen Kebijakan Dividen dan variabel independen Pertumbuhan Penjualan, Jaminan Aset, Ukuran Perusahaan, Return on Equity, Current Ratio dan Earning per Share. 


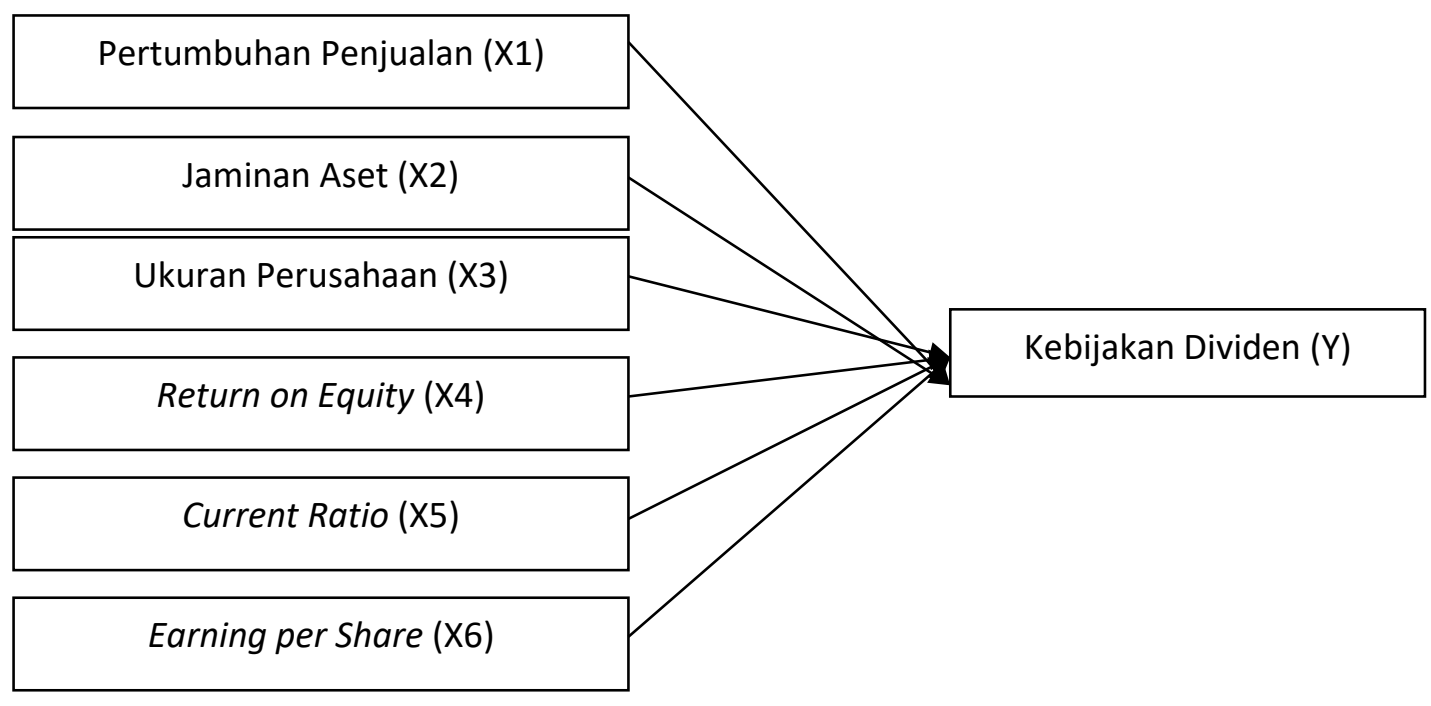

\section{METODE PENELITIAN}

Metode pengambilan sampel yang digunakan adalah metode purposive sampling, yaitu teknik penentuan sampel dengan mempertimbangkan kriteria tertentu (Sugiyono 2014, 122).

\section{Tabel 1 Prosedur Pemilihan Sampel}

\begin{tabular}{ll}
\hline \hline \multicolumn{1}{c}{ Kriteria Pemilihan Sampel } & Jumlah \\
\hline $\begin{array}{l}\text { Perusahaan sektor otomotif yang konsisten terdaftar di Bursa Efek Indonesia } \\
\text { dari tahun } 2012 \text { sampai tahun } 2015\end{array}$ & 12 \\
Total perusahaan sektor otomotif yang mempunyai data tidak outlier & 8 \\
Jumlah periode yang mempunyai data tidak outlier & 4 \\
Total pengamatan & 32 \\
\hline \hline
\end{tabular}

Berdasarkan tabel 1 terdapat 12 perusahaan sektor otomotif yang secara konsisten terdaftar di Bursa Efek Indonesia dari tahun 2012-2015, 8 perusahaan yang mempunyai data tidak outlier, dengan jumlah periode yang datanya tidak outlier yaitu 4 tahun. Maka total data yang digunakan dalam penelitian adalah sebesar 32 . Definisi Operasional Variabel dan Pengukurannya 
Tabel 2 Definisi Operasional Variabel dan Pengukurannya

\begin{tabular}{|c|c|c|}
\hline Variabel & Definisi & Rumus \\
\hline $\begin{array}{l}\text { Dividend } \\
\text { Payout Ratio } \\
\text { (DPR) }\end{array}$ & $\begin{array}{l}\text { Dividend payout ratio merupakan persentase } \\
\text { setiap keuntungan yang diperoleh dan } \\
\text { distribusikan kepada pemegang saham } \\
\text { dalam bentuk uang tunai (Sarmento dan } \\
\text { Dana 2016). }\end{array}$ & $\mathrm{DPR}=\frac{\text { Dividen per Share }}{\text { Earning per Share }}$ \\
\hline $\begin{array}{l}\text { Pertumbuha } \\
n \text { Penjualan } \\
(P P)\end{array}$ & $\begin{array}{l}\text { Pertumbuhan penjualan adalah kenaikan } \\
\text { penjualan dari tahun sebelumnya ke tahun } \\
\text { berikutnya (Darmayanti dan Mustanda 2016). }\end{array}$ & $\mathrm{PP}=\frac{\text { Penjualan } t_{1}-\text { Penjualan } t_{-1}}{\text { Penjualan } t_{-1}}$ \\
\hline $\begin{array}{l}\text { Jaminan } \\
\text { Aset (JA) }\end{array}$ & $\begin{array}{l}\text { Jaminan aset merupakan besarnya aset } \\
\text { tetap yang dapat dijaminkan oleh } \\
\text { perusahaan kepada kredior, sehingga } \\
\text { menggunakan rumus perbandingan antara } \\
\text { aset tetap dengan total aset suatu } \\
\text { perusahaan (Darmayanti dan Mustanda } \\
\text { 2016). }\end{array}$ & $J A=\frac{\text { Totsl Aset Tetap }}{\text { Total Aset }} X 100 \%$ \\
\hline $\begin{array}{l}\text { Ukuran } \\
\text { Perusahaan } \\
\text { (UP) }\end{array}$ & $\begin{array}{l}\text { Ukuran perusahaan adalah skala besar } \\
\text { kecilnya perusahaan yang ditentukan oleh } \\
\text { total aset perusahaan (Darmayanti dan } \\
\text { Mustanda 2016). }\end{array}$ & UP $=$ Ln (Total Aset) $\times 100 \%$ \\
\hline $\begin{array}{l}\text { Return on } \\
\text { Equity (ROE) }\end{array}$ & $\begin{array}{l}\text { Return on equity dihitung dari perbandingan } \\
\text { earning after tax dan total equity pada } \\
\text { laporan keuangan perusahaan (Sarmento } \\
\text { dan Dana 2016). }\end{array}$ & $\mathrm{ROE}=\frac{E A T}{\text { Total Equity }} \times 100 \%$ \\
\hline $\begin{array}{l}\text { Current Ratio } \\
\text { (CR) }\end{array}$ & $\begin{array}{l}\text { Current ratio adalah kemampuan } \\
\text { perusahaan untuk melunasi kewajiban } \\
\text { jangka pendeknya (Sarmento dan Dana } \\
\text { 2016). }\end{array}$ & $\mathrm{CR}=\frac{\text { Aktiva Lancar }}{\text { Kewajiban Lancar }} \times 100 \%$ \\
\hline $\begin{array}{l}\text { Earning per } \\
\text { Share (EPS) }\end{array}$ & $\begin{array}{l}\text { Earning per share adalah rasio yang } \\
\text { menunjukan laba bagi setiap saham suatu } \\
\text { perusahaan (Sarmento dan Dana 2016). }\end{array}$ & $\begin{array}{ll}\text { EPS } & \\
& \text { Laba bersih }\end{array} \times 100$ \\
\hline
\end{tabular}

Ada beberapa alat uji statistik yang digunakan untuk menganalisa data yang telah diperoleh, antara lain statistik deskriptif (nilai rata-rata, nilai minimum, nilai maksimum, dan standar deviasi), uji data panel, uji normalitas residual, uji asumsi klasik (multikolinearitas, heteroskedastisitas, dan autokorelasi), persamaan regresi, serta pengujian hipotesis 
(koefisien korelasi, koefisien determinasi, uji $F$, dan uji t). Pengolahan data pada penelitian ini menggunakan program Eviews versi 8

Penelitian ini menggunakan model persamaan analisis regresi. Model persamaan regresi dalam penelitian ini adalah sebagai berikut:

$D P R=\beta 0+\beta 1 P P+\beta 2 J A+\beta 3$ UP $+\beta 4 R O E$ $+\beta 5 C R+\beta 6$ EPS $+e$

Keterangan :

DPR : Dividend Payout Ratio (Kebijakan Dividen)

\section{HASIL PENELITIAN}

$\quad$ : Konstanta atau intercept

$\beta 1-\beta 6$ : Koefisien Regresi pada setiap variabel

PP $\quad$ : Pertumbuhan Penjualan

JA : Jaminan Aset

UP : Ukuran Perusahaan

ROE : Return on Equity

CR : Current Ratio

EPS : Earning Per Share

$\varepsilon \quad$ : error

Tabel 3 Hasil Uji Statistik Deskriptif

\begin{tabular}{llllll}
\hline Variabel & $\mathrm{N}$ & Minimum & Maksimum & Mean & Std.Deviation \\
\hline DPR & 32 & 0,000000 & 0.771400 & 0.281956 & 0.215005 \\
PP & 32 & -0.113600 & 0.292900 & 0.064672 & 0.105643 \\
JA & 32 & 0.354900 & 0.739800 & 0.571672 & 0.108944 \\
UP & 32 & 5.676100 & 23.93650 & 14.38613 & 4.709609 \\
ROE & 32 & -0.022400 & 0.730000 & 0.224913 & 0.219196 \\
CR & 32 & 0.930000 & 2.910000 & 1.715031 & 0.514678 \\
EPS & 32 & -90.00000 & 715.0000 & 214.6563 & 200.1889 \\
\hline
\end{tabular}

Pertumbuhan penjualan (PP) memiliki nilai probabilitas sebesar 0.9743 lebih besar dari alpha 0,05 dan t-Statistic sebesar -0.032611 lebih kecil dari $t$ tabel 2,0452, sehingga dapat disimpulkan bahwa Ha1 tidak diterima, yang artinya pertumbuhan penjualan (PP) tidak memiliki pengaruh terhadap dividend payout ratio.

Jaminan aset (JA) memiliki nilai probabilitas sebesar 0,0097 lebih kecil dari alpha
0,05 dan t-Statistic sebesar $-2,890291$ lebih besar dari $t$ tabel 2,0452, sehingga dapat disimpulkan bahwa $\mathrm{Ha}$ tidak dapat ditolak, artinya jaminan aset (JA) berpengaruh terhadap dividend payout ratio.

Ukuran perusahaan (UP) memiliki nilai probabilitas sebesar 0,6935 lebih besar dari alpha 0,05 dan t-Statistic sebesar $-0,400529$ lebih kecil dari t tabel 2,0452, sehingga dapat disimpulkan bahwa Ha1 tidak diterima, yang 
artinya ukuran perusahaan (UP) tidak memiliki pengaruh terhadap dividend payout ratio.

Return on equity (ROE) memiliki nilai probabilitas sebesar 0,9859 lebih besar dari alpha 0,05 dan t-Statistic sebesar 0,017874 lebih kecil dari t tabel 2,0452, sehingga dapat disimpulkan bahwa Ha1 tidak diterima, yang artinya return on equity (ROE) tidak memiliki pengaruh terhadap dividend payout ratio.

Current ratio (CR) memiliki nilai probabilitas sebesar 0,1036 lebih besar dari alpha 0,05 dan t-Statistic sebesar 1,714646 lebih kecil dari t tabel 2,0452, sehingga dapat disimpulkan bahwa Ha1 tidak diterima, yang artinya current ratio (CR) tidak memiliki pengaruh terhadap dividend payout ratio.

Earnings per share (EPS) memiliki nilai probabilitas sebesar 0,0975 lebih besar dari alpha 0,05 dan t-Statistic sebesar $-1,748142$ lebih kecil dari t tabel 2,0452, sehingga dapat disimpulkan bahwa Ha1 tidak diterima, yang artinya earning per share (EPS) tidak memiliki pengaruh terhadap dividend payout ratio.

\section{PENUTUP}

Berdasarkan hasil analisis dan pembahasan mengenai faktor-faktor yang mempengaruhi kebijakan dividen (dividend payout ratio), maka diperoleh kesimpulan sebagai berikut pertumbuhan penjualan tidak berpengaruh terhadap kebijakan dividen. Hasil penelitian ini konsisten dengan penelitian yang dilakukan oleh Darmayanti dan Mustanda (2016). Namun tidak konsisten dengan penelitian yang dilakukan oleh Winatha (2001), Dhailami (2006) dan Nurmadinah (2014) yang menyatakan bahwa terdapat pengaruh pertumbuhan penjualan terhadap kebijakan dividen. Jaminan Aset berpengaruh terhadap kebijakan dividen. Hasil penelitian ini konsisten dengan penelitian yang dilakukan oleh Darmayanti dan Mustanda (2016). Namun tidak konsisten dengan penelitian yang dilakukan oleh Setiawan dan Etna (2013) yang menyatakan bahwa jaminan aset tidak berpengaruh terhadap kebijakan dividen.

Ukuran perusahaan tidak berpengaruh terhadap kebijakan dividen. Hasil ini konsisten dengan penelitian yang dilakukan oleh Darmayanti dan Mustanda (2016). Namun tidak konsisten dengan penelitian yang dilakukan oleh Hatta (2002), Puspita (2009) dan Dyah (2010) yang menyatakan terdapat pengaruh ukuran perusahaan terhadap kebijakan dividen.

Return on equity tidak berpengaruh terhadap kebijakan dividen. Hasil ini konsisten dengan penelitian yang dilakukan oleh Mardaleni (2014). Namun tidak konsisten dengan penelitian yang dilakukan oleh Sarmento dan Dana (2016) yang menyatakan terdapat pengaruh return on equity terhadap kebijakan dividen.

Current ratio tidak berpengaruh terhadap kebijakan dividen. Hasil ini konsisten dengan penelitian yang dilakukan oleh Muhammadinah dan Jamil (2015). Namun tidak konsisten dengan penelitian yang dilakukan oleh Sarmento dan Dana (2016), Dewi (2014), dan Setiowati (2013) yang menyatakan bahwa ukuran perusahaan memiliki pengaruh terhadap kebijakan dividen.

Earnings per share tidak berpengaruh terhadap kebijakan dividen. Hasil penelitian ini konsisten dengan penelitian Sarmento dan Dana (2016), Suryanita dan Akbar (2014) dan Purwanti \& Sawitri (2011). Namun tidak konsisten dengan penelitian yang dilakukan oleh Dentiana (2009), Diana (2010) dan Imran (2011) menyatakan bahwa terdapat pengaruh earnings per share terhadap kebijakan dividen. 


\section{REFERENCES:}

Darmayanti dan Mustanda. 2016. Pengaruh Pertumbuhan Penjualan, Jaminan Aset, dan Ukuran Perusahaan terhadap Kebijakan Dividen pada Sektor Industri Barang Konsumsi. Universitas Udayana, Bali. Jurnal Manajemen, 5(8).

Dentiana, Tita. 2009. Faktor-Faktor Yang Mempengaruhi Kebijakan Pembayaran Dividen kas. STIE Trisakti. Jurnal Bisnis dan Akuntansi, 11(1), 57-64.

Dewi, Ni Wayan Trisna. 2014. Pengaruh Struktur Modal, Likuiditas, dan Pertumbuhan Terhadap Kebijakan Dividen DI BEI. Jurnal Fakultas Ekonomi dan Bisnis Universitas Udayana.

Dhailami, A, F. 2006. Pengaruh Insider Ownership dan Risiko Pasar Terhadap Kebijakan Dividen pada Perusahaan Manufaktur yang terdaftar di Bursa Efek Jakarta Periode 200-2003, Skripsi, Universitas Islam Indonesia. Yogyakarta.

Dyah, H. 2010. Analisis faktor-faktor yang mempengaruhi Dividend Payout Ratio pada Perusahaan Manufaktur di Bursa Efek Indonesia Periode 2005-2007. Skripsi Fakultas Ekonomi Universitas Diponegoro. Semarang.

Gitman, Lawrence J, Dan Chad J. Zutter. 2015. Principles of Managerial Finance. 14th Edition. United States of America: Pearson.

Isabella dan Apit Susanti, 2017. Faktor-Faktor Yang Mempengaruhi Devidend Payout Ratio Pada Perusahaan Non Keuangan. Jurnal Bisnis dan Akuntansi, 19(2).

Kesuma, Ali. 2009. Analisis Faktor Yang Mempengaruhi Struktur Modal Serta Pengaruhnya Terhadap Harga Saham Perusahaan Real Estate Yang Go Public Di Bursa Efek Indonesia. Jurnal Manajemen Dan Kewirausahaan, 11(1), 38-45.

Khan, Kanwal Iqbal, Muhammad Anmir, Arslan Qayyum, Adeel Nasir and Maryam Iqbal Khan. 2011. Can Dividen Decisions Affect The Stock Prices: A Case of Dividend Paying of CSE. International Research Journal of Finance and Economics, 76(68), 69-74.

Mardaleni. 2014. Analisis Pengaruh return on equity, debt equity ratio dan current ratio terhadap dividen payout ratio pada perusahaan property dan real estate yang terdaftar di Bursa Efek Indonesia Periode 20102012. E-Jurnal Apresiasi Ekonomi, 2(2).

Nurmadinah, D. 2014. Pengaruh Current Ratio, Debt to Equity Ratio, Growth, Collateralizable Aset, Return on Equity Terhadap Dividend Payout Ratio. Jurnal Akuntansi, 9(2), 556-839.

Santoso, H. 2012. Analisis Faktor-Faktor Yang Mempengaruhi Kebijakan Dividen. Skripsi, Universitas Diponegoro.

Setiawan, Y., dan Etna, N. A. Y. 2013. Pengaruh Independen Dewan Komisaris, Reputasi Auditor, Rasio Hutang dan Collateralizable Aset terhadap Kebijakan Dividen, Journal of Accounting, 3(1), 1-11.

Setiowati, Yuni. 2013. Pengaruh Current Ratio, Debt to Equity Ratio, Earning Per Share dan Return On Asset terhadap Dividend Payout Ratio Pada Perusahaan yang termasuk dalam Daftar Efek Syariah (DES) Periode 2008-2010. Skripsi Sarjana Fakultas Ekonomi, Universitas Negeri Semarang. Semarang.

Sugiyono. 2014. Metode Penelitian Bisnis: Pendekatan Kuantitatif, Kualitatif, Dan R\&D. Bandung. Alfabeta.

Suweta, Ni Made Novione Purnama Dewi Dan Made Rusmala Dewi. 2016. Pengaruh Pertumbuhan Penjualan, Struktur Aktiva, Dan Pertumbuhan Aktiva Terhadap Struktur Modal. E-Jurnal Manajemen Unud. 5(8), 5172-5199.

Wiagustini, N. L. P. 2010. Dasar-dasar manajemen keuangan. Edisi Pertama. Penerbit : Universitas Udayana Press.

Winatha. 2001. Pengaruh EPS, Cash Ratio, DER, Growth of Sale, Growth of Asset, Corporate Tax, Size of Firm terhadap DPR pada Perusahaan yang Terdaftar di Bursa Efek Indonesia. Jurnal Manajemen, 7(1), 67-92. Universitas Diponogoro 
